\title{
Study of Burden Among Caregivers of Children with Cleft Lip and Palate ${ }^{1}$
}

\author{
Ana Paula Ribeiro Razera ${ }^{2}$ \\ Universidade de São Paulo, \\ Bauru-SP, Brazil \\ Maria de Lourdes Merighi Tabaquim \\ Universidade de São Paulo, \\ Bauru-SP, Brazil
}

\author{
Armando dos Santos Trettene \\ Universidade de São Paulo, \\ Bauru-SP, Brazil
}

Ana Vera Niquerito

Universidade de São Paulo, Bauru-SP, Brazil

\begin{abstract}
The psychological and physical health of caregivers of children with cleft lip and palate can be strongly influenced by the child's condition and behavior, and care required by the treatment. This study's objective was to identify overload levels among these caregivers. A total of 100 caregivers, whose children were in the perioperative period of cheiloplasty and/or palatoplasty, were interviewed using the Scale Burden Interview. The data were analyzed quantitatively. Moderate and moderate severe burden levels were identified in $43 \%$ of the sample. The mothers of children aged around 12 months presented significantly higher overload. The results indicate that children in this developmental stage present greater care demand because they seek autonomy in locomotion, explore objects in their surrounding environment, and continually request communicative and affective-social interaction with their reference to greater attachment (the caregiver), which may have contributed to higher burden.
\end{abstract}

Keywords: caregivers, family relations, children, cleft lip, cleft palate

\section{Estudo da Sobrecarga em Cuidadores de Crianças com Fissura Labiopalatina}

\begin{abstract}
Resumo: A saúde psicológica e física dos cuidadores das crianças com fissura labiopalatina pode ser fortemente influenciada pela condição e comportamento da criança e pela demanda de cuidados dispensados no tratamento. Este estudo objetivou identificar os níveis de sobrecarga nesses cuidadores. Participaram 100 cuidadores cujos filhos se encontravam no período perioperatório de queiloplastia e/ou palatoplastia. A Escala Burden Interview foi utilizada como instrumento. Os dados foram analisados quantitativamente. Foram identificados níveis moderados e moderados-severos de sobrecarga em $43 \%$ da amostra. Observou-se que mães de crianças com idade em torno de 12 meses apresentaram sobrecarga significativamente maior. Os resultados foram indicativos de maior exigência de cuidados com a criança nessa fase do desenvolvimento, decorrente da busca de autonomia na locomoção, exploração de objetos no ambiente próximo, com solicitações contínuas de interação comunicativa e afetiva-social junto à referência de maior apego (o cuidador), o que pode ter contribuído para uma maior sobrecarga.
\end{abstract}

Palavras-chave: cuidadores, relações familiares, crianças, fissura labial, fissura palatal

\section{Investigación de la Sobrecarga en los Cuidadores de Niños con Fisura Labiopalatina}

\begin{abstract}
Resumen: La salud física y psicológica de los cuidadores de niños con fisura labiopalatina puede ser fuertemente influenciado por el estado y el comportamiento del niño, y por la demanda de atención prestada en el tratamiento. Este estudio tuvo como objetivo identificar los niveles de sobrecarga de estos cuidadores. Participaron 100 cuidadores de niños que estaban en el periodo perioperatorio de queiloplastia y/o palatoplastia. Fue utilizada como instrumento la Escala Burden Interview. Los datos fueron analizados cuantitativamente. Niveles leves y moderados-graves fueron identificados en el $43 \%$ de la muestra. Se observó que las madres de niños en edad alrededor de doce meses tuvieron sobrecarga significativamente mayor. Los resultados fueron indicativos de una mayor demanda de cuidados para el niño en esta fase de desarrollo, debido a la búsqueda de autonomía en la locomoción, la exploración de los objetos en el entorno circundante, con continuas solicitaciones de interacción comunicativa y afectivo-sociales, juntamente con la referencia de mayor apego (el cuidador), lo que puede haber contribuido a una sobrecarga mayor.
\end{abstract}

Palabras clave: cuidadores, relaciones familiares, niños, labio leoporino, paladar fissurado

\footnotetext{
${ }^{1}$ Paper derived from the doctoral dissertation by the first author, under the advice of the last author, defended in the Graduate Program in Rehabilitation Sciences of the Hospital for Rehabilitation of Craniofacial Anomalies at the University of São Paulo.

Support: Foundation for Research Support of the State of São Paulo (FAPESP, Grant \# n 2012/18085-0).

${ }^{2}$ Correspondence address:

Ana Paula Ribeiro Razera. Departamento de Enfermagem. Rua Silvio Marchione 3-20, Vila Universitária. CEP 17012-900. Bauru-SP, Brazil. E-mail: anapaularazera@usp.br
}

Cleft lip (CL), cleft palate (CP) and cleft lip and palate (CLP) are congenital deformities characterized by a lack of continuity of central structures of the middle face and palatine process and intensely affect patients' lives from the time of birth due to the functional and aesthetic changes, which psychologically impact the affected individual, with repercussions for the family and in other social environments (Paranaíba, Miranda, Ribeiro, Barros, \& Martelli Junior, 2011). 
Cases of orofacial cleft, a group of disorders including CL, CP and CLP, affects an average of one out of every 700 live births (Dixon, Marazita, Beaty, \& Murray, 2011; Freitas et al., 2012). This prevalence vary according to ethnicity, being more prevalent among individuals of Asian descent (1 out of 440 live births) followed by Caucasians (1 out of 650) and Afro-descendant (1 out of 2,000 live births). In Brazil, the mean prevalence of orofacial cleft has been recorded as being about 1 for every 650 live births (Freitas et al., 2012; Paranaíba et al., 2011). Thus, the high rate of occurrence of these disorders fully justifies a concern within the scope of public health, not only with the patients themselves but also with the monitoring of the quality of life of parents and guardians who are responsible for children affected by this craniofacial disorder.

The process of rehabilitation of labio-palatal fissures starts with primary plastic surgery, particularly the procedures of cheiloplasty (lip reduction) and palatoplasty (palate reconstruction), respectively performed in the first months and years of life, respectively. However, the rehabilitation process is by no means restricted to the anatomical repair of the fissure, as the consequences for the child vary depending on the fissure type and size, especially because it affects basic functions like speech, hearing, development of occlusion, and craniofacial growth, in addition to physiological development and psychological and social adaptation. The needs of this population require investment in rehabilitation, with the inclusion of interdisciplinary teams, particularly at critical times of the child's development (Paranaíba et al., 2011).

During child development, there is an increase in skills that are important for the child's adaptation, also significantly interfering in his/her capacity to carry out increasingly complex activities. Therefore, in the child's first years of life, sensorial and motor learning is essential for bodily control while performing daily activities, which results from neurological maturation and interaction with the psychosocial context. In this period, the child develops numerous body movements, including rolling, climbing and exploring objects. Parents normally consider it to be a difficult phase that requires constant assistance, resulting from the evolutionary advancement of the child's growth and development (Kyle, 2011; Marcondes, Vaz, Ramos, \& Okay, 2003).

This time of the child's life coincides with palatoplasty, the primary demand of which includes changes in the child's eating habits, such as consistency of the food and the utensil used to feed the child. Note that, at this point, the child already has food preferences and has also established methods by which food is administered (Trettene, Mondini, \& Marques, 2013).

Even though the use of a bottle after cheiloplasty is still widely accepted, its use after a palatoplasty is somewhat controversial, as it is the most invasive surgical procedure among primary surgical operations. In this context, a glass and a spoon are highly feasible alternatives, as they are cheap, easy to handle, and also easy to clean (Trettene et al., 2013).

Also in this period, caregivers should be advised that feeding the child should be resumed after returning from the operating room, with the introduction of a cold and liquid diet for a period of 30 days (Trettene et al., 2014). Evidently, such changes in the child's feeding routine, associated with other post-surgical care, leads caregivers to experience a high level of stress, potentially leading to caregiver burden.

Therefore, the psychological and physical health of caregivers may be strongly influenced by the child's condition and behavior, as well as by the care demands that are part of the treatment of labio-palatal fissure. In the period after surgery, there is also increased responsibility linked to the child's recovery, which exposes caregivers to the risk of burden, fatigue, social isolation, and greater stress (Raina et al., 2005). The impact of such an injury is normally a difficult experience and, in the case of a surgery, caregivers experience different levels of anxiety, resulting from the condition associated with the surgical risk, which may even intensify psychosomatic symptoms (Manoel, Teston, Waidman, Decesaro, \& Marcon, 2013). Hence, the changes that occur in the lives of caregivers may affect their health and, consequently, affect the rehabilitation process of children with labio-palatal fissure.

On the other hand, the duration and intensity of emotional responses are strongly linked to how the parents cope with the problem. The more visible the child's physical defects are, the more immediate and more intense the emotional responses and concerns will be. Initial reactions may be minimized if, immediately after birth, the parents receive specific information and appropriate guidance on how to handle and treat this condition, reducing the potential emotional impact resulting from damage, risks, and other stressful contingency situations (Tabaquim \& Marquesini, 2013; Trettene et al., 2014).

Self-perception and stress management on the part of the caregiver, prior to the child's labio-palatal fissure, are directly linked to the caregiver's ability to solve problems and, as a result, to his/her psychological well-being, and not necessarily to the physical strain resulting from the care. The higher one's self-esteem and the greater one's sense of understanding what care is necessary, the better is one's psychological well-being (Raina et al., 2005).

Therefore, the relationship between situations of stress faced by caregivers and physical and psychological symptoms can be mediated by coping, in which one's perception of selfefficiency and competence (coping strategies) are able to mediate the relationship between a stressful event and distress experienced by the caregiver, thereby resulting in better health and decreased burden (Salin, Kaunonen, \& AstedtKurki, 2009).

The concept of burden involves two different aspects, the objective and subjective (Tessler \& Gamache, 1996). Objective caregiver burden is determined based on the frequency of assistance and supervision, as part of a patient's daily routine care, and the frequency of changes in the routine of the caregiver's life; i.e., it refers to concrete demands including an excessive number of tasks, supervision of behavior, financial difficulties, and disturbances in routine and social life. Subjective overload is determined according to the degree of inconvenience experienced by the family caregiver and his/her concern for the patient, as it is also related to feelings, concerns with the present and future of the patient, discomfort in dealing with problems, and also loss, guilt, disgrace, impotence, and helplessness (Kate, Grover, Kulhara, \& Nehra, 2013). 
The literature presents numerous studies addressing the effects of caregiver overload in different populations (Cardoso, Vieira, Ricci, \& Mazza, 2012; Guedes \& Pereira, 2013; Hansen, Vedana, Miasso, Donato, \& Zanetti, 2014; Macedo, Silva, Paiva, \& Ramos, 2015; Manoel et al., 2013; Misquiatti, Brito, Ferreira, \& Junior, 2015; Monteiro, Mazin, \& Dantas, 2015; Pereira, Santos, Fhon, Marques, \& Rodrigues, 2013; Scazufca, 2002; Souza et al., 2015; Valer, Aires, Fengler, \& Paskulin, 2015), but the literature in relation to the burden of those caring for children with labio-palatal fissure is still incipient. Hence, there is a need to identify burden through impacting objective and subjective factors that can characterize health, personal and social life, emotional behavior, and general well-being among caregivers, seeking to contribute to the planning of interdisciplinary actions, directed to both the child and family. Therefore, this study's objective was to identify burden levels among caregivers of children with labio-palatal fissure.

\section{Method}

\section{Participants}

This cross-sectional and descriptive study included interviews of 100 female caregivers, aged between 18 and 50 years old, with at least primary education, and whose children were in the intraoperative period for primary reparatory surgery of cheiloplasty and/or palatoplasty. Inclusion criteria were: being the informal caregiver of a child with isolated labio-palatal fissure, aged between 3 and 24 months; being an informal caregiver responsible for care on a daily basis; being 18 years old or older; and having consented to participate in the study. Caregivers of children with neuropsychological problems, genetic and/or clinical syndromes, or other malformations or comorbidities, who needed special care, were excluded. Sampling considered a test power of $80 \%$, statistical significance of $5 \%$, standard deviation and difference of $20 \%$ from the mean value of the Burden Interview Scale (Scazufca, 2002).

\section{Instruments}

Burden Interview Scale - BI (Zarit, Reever, \& Bach-Peterson, 1980): this scale was developed to assess burden among the parents or informal caregivers of patients with physical, sensorial or mental impairment. This instrument consists of 22 questions, including the fields of health, social and personal life, financial situation, general well-being, emotional behavior, and interpersonal relationships. The score for each answer ranges from 0 to 4 , in which 0 -never, 1-rarely, 2-sometimes, 3-often, and 4-always. The scale's items globally assess how much the family caregiver feels overloaded by the care provided to the child. The possible answers to these items and corresponding scores are: 0 -not at all; 1-a little; 2-moderately; 3-a lot; and 4-very much. The final BI score is obtained by adding all the scores, which can range from 0 to 88 . The higher the final score, the greater is the caregiver burden (Zarit et al., 1980). The BI scale was translated and validated for the Brazilian population by Scazufca (2002) and assesses caregiver burden for mentally impaired individuals. The Scale's psychometric properties were analyzed by calculating the correlations among the answers for each item, as well as the correlation of the total number of items and the Cronbach Alpha Coefficient, which resulted in an index of 0.87 (Scazufca, 2002).

Sociodemographic Questionnaire: this instrument addressed social and demographic information, such as: children's gender, age, type of fissure and surgical procedure, as well as caregiver's age, marital status, educational level, socioeconomic status and number of children.

\section{Procedure}

Data Collection. The study was conducted between August and October 2014, in a public hospital, a reference center in the care provided to patients with craniofacial anomalies. Data were collected during the hospitalization of children in the intraoperative phase, a time when children were undergoing cheiloplasty and/or palatoplasty surgeries, and lasted 30 minutes on average. The interviews were held in a private room on the hospital's premises. The participants received clarification of the study's objectives and the instruments used for data collection. An intentional sample was used and, for the sake of convenience, the subjects were selected consecutively.

Data Analysis. Data were descriptively analyzed and then subjected to statistical analysis, using the Chi-square test to verify correlation between caregiver burden and the variables: children's gender, type of fissure and surgical procedure, and the caregiver's marital status, educational level, socioeconomic status and number of children. The Kruskal-Wallis test was used to compare caregiver overload and the child's age, while analysis of variance (ANOVA) was used to compare caregiver burden and caregiver's age. A significance level of $5 \%(p \leq 0.05)$ was used for all the tests.

\section{Ethical Considerations}

This study was approved by the Institutional Review Board (CAAE: 09750212.8.0000.5441 and protocol 190.581 from January 29 $9^{\text {th }}, 2013$ ) and all the participants signed informed consent forms in accordance with the guidelines of Resolution 466/2012 National Health Council concerning research involving human subjects.

\section{Results}

Most of the caregivers were mothers (98\%); aged 28 years $( \pm 6)$ on average; were in a stable relationship ( $83 \%)$; did not have a paid job (58\%); had attended high school (52\%); had a low socioeconomic status ( $89 \%$ ); and had only one child (48\%). Fifty of the children cared for were girls, and 50 were boys, with an average age of 10 months $( \pm 8)$. Regarding the type of fissure, $20 \%$ had cleft lip (CL), 37\% had cleft palate (CP) and 43\% had cleft lip and palate (CLP); 36\% underwent 
cheiloplasty, 37\% palatoplasty, and 27\% underwent both cheiloplasty and palatoplasty.

Regarding the assessment of caregiver burden using the BI scale, a minimum score of 4 points and a maximum of 54 were found, with a mean of 20.15 and standard deviation (SD) of 11.27 . A total of $57 \%$ of the caregivers did not show evidence of burden; however, $43 \%$ scored 21 points or greater, i.e., presented a moderate $(36 \%)$, or moderatesevere $(7 \%)$, burden.

Tables 1 and 2 show comparisons between caregiver burden and variables related to the children and caregivers.
No statistical significance was found when caregiver overload was associated with the children's variables: gender $(p=0.873)$, type of fissure $(p=0.132)$ or surgical procedure $(p=0.111)$, or with variables related to caregivers: age $(p=0.300)$, marital status $(p=0.414)$, educational level $(p=0.973)$, socioeconomic classification $(p=0.714)$ or number of children $(p=0.506)$. When, however, caregiver burden was associated with the child's age, a statistically significant difference was found, i.e., the mothers of children aged around twelve months experienced the greatest overload.

Table 1

Comparison of Caregivers Burden with Children's Characterization

\begin{tabular}{|c|c|c|c|c|c|c|c|}
\hline \multirow[t]{2}{*}{ Variables } & \multicolumn{2}{|c|}{ Absent } & \multicolumn{2}{|c|}{ Moderate } & \multicolumn{2}{|c|}{ Moderate/Severe } & \multirow[t]{2}{*}{$p$} \\
\hline & $M$ & $\pm S D$ & $M$ & $\pm S D$ & $M$ & $\pm S D$ & \\
\hline \multirow[t]{2}{*}{ Age (months) } & 8.7 & 6.9 & 12.9 & 9.6 & 8.4 & 3.6 & $0.035 \alpha^{*}$ \\
\hline & $n$ & $\%$ & $n$ & $\%$ & $n$ & $\%$ & $p$ \\
\hline \multicolumn{8}{|l|}{ Gender } \\
\hline Female & 29 & 50.9 & 17 & 47.2 & 4 & 57.1 & $0.873 \beta$ \\
\hline Male & 28 & 49.1 & 19 & 52.8 & 3 & 42.9 & \\
\hline \multicolumn{8}{|l|}{ Type of fissure } \\
\hline Cleft Lip (CL) & 13 & 22.8 & 7 & 19.4 & 0 & 0 & \multirow{2}{*}{$0.132 \beta$} \\
\hline Cleft Palate (CP) & 19 & 29.8 & 18 & 50 & 2 & 28.6 & \\
\hline Cleft Lip and Palate (CLP) & 27 & 47.4 & 11 & 30.6 & 5 & 71.4 & \\
\hline \multicolumn{8}{|l|}{ Surgical Procedure } \\
\hline Cheiloplasty & 24 & 42.1 & 11 & 30.6 & 1 & 14.3 & \multirow{2}{*}{$0.111 \beta$} \\
\hline Palatoplasty & 17 & 29.8 & 18 & 50 & 7 & 19.4 & \\
\hline Cheiloplasty and Palatoplasty & 16 & 28.1 & 7 & 19.4 & 4 & 57.1 & \\
\hline
\end{tabular}

Note. $\alpha$ Kruskal-Wallis; $\beta$ Chi-Square Test; * Significance of 5\%

Table 2

Comparison of Caregiver Burden with Caregivers' Sociodemographic Variables

\begin{tabular}{|c|c|c|c|c|c|c|c|}
\hline \multirow[t]{2}{*}{ Variables } & \multicolumn{2}{|c|}{ Absent } & \multicolumn{2}{|c|}{ Moderate } & \multicolumn{2}{|c|}{ Moderate to Severe } & \multirow[t]{2}{*}{$p$} \\
\hline & $M$ & $\pm S D$ & $M$ & $\pm S D$ & $M$ & $\pm S D$ & \\
\hline \multirow[t]{2}{*}{ Age (years) } & 28.8 & 6.4 & 27.4 & 5.4 & 25.9 & 2.9 & $0.300 \Omega$ \\
\hline & $n$ & $\%$ & $n$ & $\%$ & $n$ & $\%$ & $p$ \\
\hline \multicolumn{8}{|l|}{ Marital Status } \\
\hline Stable Union & 46 & 80.7 & 32 & 82.9 & 5 & 71.4 & $0.414 \beta$ \\
\hline Single & 11 & 19.3 & 4 & 11.1 & 2 & 28.6 & \\
\hline \multicolumn{8}{|l|}{ Educational Level } \\
\hline Primary/middle school & 15 & 26.3 & 8 & 22.2 & 2 & 28.6 & \multirow{3}{*}{$0.973 \beta$} \\
\hline High school & 29 & 50.9 & 20 & 55.6 & 3 & 42.9 & \\
\hline College & 13 & 22.8 & 8 & 22.2 & 2 & 28.6 & \\
\hline \multicolumn{8}{|l|}{ Socioeconomic Classification } \\
\hline Lower-class & 52 & 91.2 & 31 & 86.1 & 6 & 85.7 & \multirow[t]{2}{*}{$0.714 \beta$} \\
\hline Middle-class & 5 & 8.8 & 5 & 13.9 & 1 & 14.3 & \\
\hline \multicolumn{8}{|l|}{ Number of children } \\
\hline 1 & 28 & 49.1 & 16 & 44.4 & 4 & 57.1 & \multirow{3}{*}{$0.506 \beta$} \\
\hline 2 & 13 & 22.8 & 9 & 25 & 3 & 42.9 & \\
\hline 3 or more & 16 & 28.1 & 11 & 30.6 & 0 & 0 & \\
\hline
\end{tabular}

Note. $\Omega$ Analysis of Variance (ANOVA); $\beta$ Chi-Square Test. 
Analysis of the most common answers given by caregivers for each component of the scale shows that $100 \%$ of participants report their children depended on the same caregiver, while $73 \%$ reported that, in general, they felt overloaded in taking care of the child, and $67 \%$ reported that, because of the time they spent providing care to the child, they did not have enough time to take care of themselves. In addition, $59 \%$ reported that they felt stressed, having to provide care to the child along with other family responsibilities and work; $53 \%$ reported they felt unsure about what to do for the child; $51.5 \%$ said that they could provide better care than they were providing and should be doing more for the child; and $49 \%$ said that the child asks for more help than s/he really needs.

\section{Discussion}

The sample was homogeneous in regard to gender, though labio-palatal fissures are more frequent among boys, while isolated cleft palate (CP) is more prevalent among girls (Cymrot et al., 2010). The children were aged 10 months on average; labio-palatal fissure was more prevalent; and children underwent cheiloplasty and palatoplasty procedures, which show that the protocol concerning primary surgeries according to the age of the child was followed; a similar result is presented by Trettene et al., (2013). These surgeries, when carried out at the appropriate time, contribute to different aspects for the success of the rehabilitation process of the child with a labio-palatal fissure (Palandi \& Guedes, 2011).

In analysis of the caregivers' social and demographic data, mothers were more frequently the person responsible for the care provided to the child with labio-palatal fissure, in line with what is reported in the literature (Trettene et al., 2014). Mothers are the main caregivers of children with labiopalatal fissure, and a strong bond between mother and child is extremely important for the child's rehabilitation (Quirino, Collet, \& Neves, 2010). A study conducted by Bandeira, Tostes, Santos, Lima and Oliveira (2014) reports that women showed higher levels of burden, and also compose the largest share of caregivers, while burden is linked to greater responsibility, time demands, and dedication.

The mothers were aged 28 years old on average and most were in a stable union, also in accordance with literature (Trettene et al., 2013; Trettene et al., 2014). Note the importance of the participation of the family as a whole in the rehabilitation of the child with labio-palatal fissure, in which the presence of the father appears not as a reflection or alternative for the close relationship of the child and mother, but as an aspect extremely important for the child's development (Bandeira et al., 2014).

Additionally, most of the caregivers did not have a paid job, which may be a consequence of the need to be fully available to accompany the child during rehabilitation, considering that labio-palatal fissures may cause all types of problems (Paranaíba et al., 2011). Working mothers are less available to provide care to the child, though this does not necessarily mean there is burden from a psychological and functional perspective. Aspects such as child's dependency may require the caregiver to be available, but do not necessarily imply emotional distress for caregivers (Tabaquim, Moura-Ribeiro, \& Ciasca, 2015).
In terms of education, the prevalence of high school and a low socioeconomic status is also in agreement with results reported in the literature (Trettene et al., 2014). Regarding the number of children, caregivers with one child are the norm, also in agreement with one study (Martelli et al., 2010). Therefore, the more children one has, the less time one has available to provide care to a child with special needs (Trettene et al., 2014).

All those interviewed in this study were informal caregivers who identified themselves as being responsible for a child with labio-palatal fissure. This study's results show moderate to moderate-severe burden. Such a result presents statistical significance when caregiver burden is associated with children's age, indicating that children aged twelve months lead to the greatest probability of burden.

The burden experienced by the caregivers of children aged twelve months may be related to the conditions of the caregiver and his/her adaptation to the situation of having a child with labio-palatal fissure at a critical time of child development, i.e., when the child is acquiring motor skills, such as walking, comprehension and communication, a time when the child has the systematic need to explore his/her environment, without understanding of control or censure, which requires constant supervision by an adult.

Difficulty breastfeeding is the first obstacle that a child with labio-palatal fissure has to face, as it is a factor considered to be a risk for early weaning, due to the mother's doubts about how to deal with the needs of a baby with this anomaly. Malformation often has a negative effect on the feeding of infants, and becomes a major challenge for both caregiver and child (Di Ninno et al., 2010). One recent study shows that most mothers of children with labio-palatal fissure breastfed their children for 29 days on average, which is well below the recommended time period (Santos et al., 2011).

According to Di Ninno et al. (2010), labio-palatal fissures lead to considerable constraints on breastfeeding, due to anatomical issues that make lip-sealing more difficult and also hinder the formation of the negative intraoral pressure that is essential for efficient suckling. This can bring a range of difficulties to the child: fatigue during breastfeeding; prolonged feeding; growth may be compromised; weight loss; iron deficiency anemia; and therefore, additional concerns on the part of the mothers such as fear of not being sufficiently capable of taking care of their children (Santos et al., 2011).

The phase immediately after breastfeeding can also be a period of caregiver burden, as it is linked to the establishment of eating habits for children with labio-palatal fissure, a major cause of concern for parents and caregivers (Trettene et al., 2013). The concern over eating habits, somewhat lessened after birth, reemerges with palatoplasty, recommended for children at a minimum age of twelve months, mainly due to the reconstructed anatomic site. Additionally, the child may have already established eating routines and food preferences that are not always appropriate, requiring the caregiver to make an effort to encourage the learning of new experiences and also promote adjusted and non-controlling behavior patterns (Trettene et al., 2013).

The study conducted by Trettene et al. also reports that the caregivers spent a significant amount of time caring for their 
children and did not have enough time to care for themselves. Caregivers of children with labio-palatal fissure experience limitations on their personal lives, which impacts their daily routine due to the time spent with child rehabilitation, along their own health problems that may occur concomitantly with their child's condition, and the need to make changes, both in the caregiver's life and in the lives of other family members, seeking to adapt and adjust to the recurring primary needs of the child as a patient (Martins, Ribeiro, \& Garrett, 2003).

Another issue that may also lead to caregiver burden is the importance of treating labio-palatal fissures in specialized centers, with a multidisciplinary team. This also generates a certain degree of stress among caregivers as they have to leave their homes on several occasions, leaving any other children in the care of third parties, such as relatives, friends and neighbors, often negatively affecting the domestic routine and well-being of the family (DiNinno et al., 2010).

The stress that is linked to the responsibilities inherent to the care of a child who fully depends on a caregiver became evident in this study. The caregivers reported they experienced stress concerning the care provided to their child, while they also had to take on other responsibilities at work and at home. Additionally, some of the caregivers reported feeling insecure, in debt to their children, as well as feeling burdened.

These feelings, a mix of impotence and exhaustion, clearly show a situation in which mental health is at risk, thereby hindering the quality of the care provided to the patient. Therefore, the participation of the family is crucial, so that care provided to the child with labio-palatal fissure may be shared with other family members, thus avoiding potential damage to the caregiver's quality of life (Bandeira et al., 2014). The identification of factors involved in caregiver burden can aid in planning care delivery, interventions, and the preparation of strategies to guide and assist caregivers of children with labio-palatal fissure (Misquiatti et al., 2015).

Hence, this study revealed the presence of objective overload, with concrete demands (Kate et al., 2013; Tessler \& Gamache, 1996) presented to caregivers, based on the high frequency of care required by the children's daily routine, constant changes in the routine of the child's social life, resulting from an excess of tasks, and also feelings of personal annulment. There has also been evidence of aspects of subjective overload, shown by discomfort, feelings of incompleteness and impotence in filling the caregiver role, even suggesting feelings of hopelessness.

One of the challenges faced by studies addressing quality of life and contingencies involving the routine and the general wellbeing of caregivers is that of using methodologies that utilize cross-sectional studies in a search for indicators of the object of study. This bias disregards other important variables that are not considered at the specific time of the study, which is restricted to use of the information participants considered the most relevant at the time, i.e., the participants may not take into account or value previously experienced feelings. Thus, longitudinal research studies addressing this issue could complement these findings and enable greater depth regarding other determinants factors.
This study identified moderate to moderate-severe levels of burden among caregivers of children with labiopalatal fissure, in the period when the child is aged around twelve months, which is considered a time of the greatest impact. Factors concerning development were suggested as contributing to greater demand and greater requirements on the part of the child in this phase of repairing the fissure and functional rehabilitation. The results suggest that children aged around 12 months old present the greatest demand for care, resulting from the child's search for independence in movement and exploration of objects in the immediate environment, with constant requests for communicative interaction and affectivesocial interaction with the person who has the closest bond (the caregiver), which may have contributed to greater overload.

Therefore, both public and private institutions providing basic health care to children, need to take into account that the satisfactory treatment of children with special needs, especially in the case of those undergoing treatment in a hospital setting, includes the caregivers' mental and physical well-being.

\section{References}

Bandeira, M., Tostes, J. G. A., Santos, D. C. S., Lima, D. C., \& Oliveira, M. S. (2014). Sobrecarga de familiares cuidadores de pacientes psiquiátricos: Relação com assertividade. [Burden in family caregivers of psychiatric patients: Relation with assertive behavior]. Psico-USF, 19(3), 399-409. doi:10.1590/1413-82712014019003003

Cardoso, L., Vieira, M. V., Ricci, M. A. M., \& Mazza, R. S. (2012). The current perspectives regarding the burden on mental health caregivers. Revista da Escola de Enfermagem da USP, 46(2), 513-517. doi:10.1590/S008062342012000200033

Cymrot, M., Sales, F. C. D., Teixeira, F. A. A., Teixeira Júnior, F. A. A., Teixeira, G. S. B., Cunha Filho, J. F., \& Oliveira, N. H. (2010). Prevalência dos tipos de fissura em pacientes com fissuras labiopalatinas atendidos em um hospital pediátrico do nordeste brasileiro. [Prevalence of kinds of cleft lip and palate at a pediatric hospital in northeast of Brazil]. Revista Brasileira de Cirurgia Plástica, 25(4), 648-657. doi:10.1590/S1983-51752010000400015

Di Ninno, C. Q. M. S., Vieira, F. C. F., Lemos, A. M. M., Silva, L. F., Rocha, C. M. G., Norton, R. C., ... Oliveira e Britto, D. B. (2010). A prevalência do uso de sonda nasogástrica em bebês portadores de fissura de lábio e/ou palato [Prevalence of the use of nasogastric tube in babies with cleft lip and/or palate]. Revista da Sociedade Brasileira de Fonoaudiologia, 15(4), 578-583. doi:10.1590/S151680342010000400017

Dixon, M. J., Marazita, M. L., Beaty, T. H., \& Murray, J. C. (2011). Cleft lip and palate: Understanding genetic and environmental influences. Nature Reviews Genetics, 12(3), 167-178. doi:10.1038/nrg2933 
Freitas, J. A. S., Neves, L. T., Almeida, A. L. P. F., Garib, D. G., Trindade-Suedam, I. K., Yaedú, R. Y. F., ... Pinto, J. H. (2012). Rehabilitative treatment of cleft lip and palate: Experience of the Hospital for Rehabilitation of Craniofacial Anomalies/USP (HRAC/USP) - Part 1: Overall aspects. Journal of Applied Oral Science, 20(1), 9-15. doi:10.1590/S1678-77572012000100003

Guedes, A. C., \& Pereira, M. G. (2013). Burden, coping, physical symptoms and psychological morbidity in caregivers of functionally dependent family members. Revista Latino-Americana de Enfermagem, 21(4), 935940. doi:10.1590/S0104116920130004000-15

Hansen, N. F., Vedana, K. G. G., Miasso, A. I., Donato, E. C. S. G., \& Zanetti, A. C. G. (2014). A sobrecarga de cuidadores de pacientes com esquizofrenia: Uma revisão integrativa da literatura [The burden of caregivers to patients with schizophrenia: A bibliographic literature review]. Revista Eletrônica de Enfermagem, 16(1), 220-227. doi:10.5216/ ree.v16i1.20965

Kate, N., Grover, S., Kulhara, P., \& Nehra, R. (2013). Relationship of caregiver burden with coping strategies, social support, psychological morbidity, and quality of life in the caregivers of schizophrenia. Asian Journal of Psychiatry, 6(5), 380-388. doi:10.1016/j.ajp.2013.03.014

Kyle, T. (2011). Enfermagem pediátrica [Pediatric nursing] (C. H. Cosendey \& I. L. Gomes, Trads.). Rio de Janeiro, RJ: Guanabara Koogan.

Macedo, E. C., Silva, L. R., Paiva, M. R., \& Ramos, M. N. P. (2015). Burden and quality of life of mothers of children and adolescents with chronic illnesses: An integrative review. Revista Latino-Americana de Enfermagem, 23(4), 769-777. doi:10.1590/01041169.0196.2613

Manoel, M. F., Teston, E. F., Waidman, M. A. P., Decesaro, M. N., \& Marcon, S. S. (2013). As relações familiares e o nível de sobrecarga do cuidador familiar [The family relationship and the burden level on family caregivers]. Escola Anna Nery, 17(2), 346-353. doi:10.1590/S141481452013000200020

Marcondes, E., Vaz, F. A. C., Ramos, J. L. A., \& Okay, Y. (2003). Pediatria básica [Basics pediatrics] (9th ed.). São Paulo, SP: Sarvier.

Martelli, D. R. B., Cruz, K. W., Barros, L. M., Silveira, M. F., Swerts, M. S. O., \& Martelli Júnior, H. (2010). Maternal and paternal age, birth order and interpregnancy interval evalution for cleft lip-palate. Brazilian Journal Otorhinolaryngology, 76(1), 107-112. doi:10.1590/ S1808-86942010000100018

Martins, T., Ribeiro, J. P., \& Garrett, C. (2003). Estudo de validação do questionário de avaliação da sobrecarga para cuidadores informais [Caregiver burden questionnaire - validation study]. Psicologia, Saúde \& Doenças, 4(1), 131-148. Retrieved from https://comum.rcaap.pt/ bitstream/10400.26/11064/1/84166.pdf
Misquiatti, A. R. N., Brito, M. C., Ferreira, F. T. S., \& Assumpção Júnior, F. B. (2015). Family burden and children with autism spectrum disorders: Perspective of caregivers. Revista CEFAC, 17(1), 192-200. doi:10.1590/1982-0216201520413

Monteiro, E. A., Mazin, S. C., \& Dantas, R. A. S. (2015). The informal caregiver burden assessment questionnaire: Validation for Brazil. Revista Brasileira de Enfermagem, 68(3), 364-370, 421-428. doi:10.1590/0034$7167.2015680307 \mathrm{i}$

Palandi, B. B. N., \& Guedes, Z. C. F. (2011). Aspectos da fala de indivíduos com fissura palatina e labial, corrigida em diferentes idades [Aspects of speech of subjects with cleft palate corrected in different ages]. Revista CEFAC, 13(1), 8-16. doi:10.1590/S15161846-2011005000012

Paranaíba, L. M. R., Miranda, R. T., Ribeiro, L. A., Barros, L. M., \& Martelli Júnior, H. (2011). Frequency of congenital craniofacial malformations in a Brazilian Reference Center. Revista Brasileira de Epidemiologia, 14(1), 151160. doi:10.1590/S1415-790X2011000100014

Pereira, R. A., Santos, E. B., Fhon, J. R. S., Marques, S., \& Rodrigues, R. A. P. (2013). Burden on caregivers of elderly victims of cerebrovascular accident. Revista da Escola de Enfermagem da USP, 47(1), 185-192. doi:10.1590/S008062342013000100023

Quirino, D. D., Collet, N., \& Neves, A. F. G. B. (2010). Hospitalização infantil: Concepções da enfermagem acerca da mãe acompanhante [Child hospitalization: nursing conceptions about the mother's companion]. Revista Gaúcha de Enfermagem, 31(2), 300-306. doi:10.1590/S1983-14472010000200014

Raina, P., O’Donnell, M., Rosenbaum, P., Brehaut, J., Walter, S. D., Russell, D., ... Wood, E. (2005). The health and well-being of caregivers of children with cerebral palsy. Pediatrics, 115(6), e626-e636. doi:10.1542/peds.20041689

Salin, S., Kaunonen, M., \& Astedt-Kurki, P. (2009). Informal carers of older family members: How they manage and what support they receive from respite care. Journal of Clinical Nursing, 18(4), 492-501. doi:10.1111/j.13652702.2008.02550.x

Santos, E. C., Leite, S. G. S., Santos, S. M. P., Neves, Z. F., Passos, X. S., \& Silveira, F. F. C. F. (2011). Análise qualitativa do padrão alimentar de crianças portadoras de fissura de lábio e/ou palato atendidas em um hospital de Goiânia-GO [Qualitative analysis of the dietary pattern of children with cleft lip and/or palate assisted at a hospital in Goiânia-GO]. Journal of the Health Science Institute, 29(3), 183-185. Retrieved from http://www3.unip.br/ comunicacao/publicacoes/ics/edicoes/2011/03 jul-set/ V29_n3_2011_p183-185.pdf 
Scazufca, M. (2002). Brazilian version of the burden interview scale for the assessment of burden of care in carers of people with mental illnesses. Revista Brasileira de Psiquiatria, 24(1), 12-17. doi:10.1590/S1516-44462002000100006

Souza, L. R., Hanus, J. S., Dela Libera, L. B., Silva, V. M., Mangilli, E. M., Simões, P. W., ... Tuon, L. (2015). Sobrecarga no cuidado, estresse e impacto na qualidade de vida de cuidadores domiciliares assistidos na atenção básica [Overload in care, stress and impact on the quality of life of surveyed caregivers assisted in primary care]. Cadernos de Saúde Coletiva, 23(2), 140-149. doi:10.1590/1414-462X201500020063

Tabaquim, M. L. M., \& Marquesini, M. A. M. (2013). Study of the stress of parents of patients with cleft lip and palate in a surgical process. Estudos de Psicologia (Campinas), 30(4), 517-524. doi:10.1590/S0103-166X2013000400005

Tabaquim, M. L. M., Moura-Ribeiro, M. V. L., \& Ciasca, S. M. (2015). Aprendizagem e paralisia cerebral [Learning and cerebral paralysis]. In N. T. Rotta, L. Ohlweiler, \& R. S. Riesgo (Orgs.), Transtornos da aprendizagem: Abordagem neurobiológica e multidisciplinar [Learning disorder: Neurobiological and multidisciplinary approach] (pp. 427-434). Porto Alegre, RS: Artmed.

Tessler, R. C., \& Gamache, G. M. (1996). The family burden interview schedule - short form (FBIS/SF). In L. I. Sederer \& B. Dickey (Eds.), Outcomes assessment in clinical practice. (pp. 110-112). Baltimore, MD: Williams \& Wilkins.

Trettene, A. S., Mondini, C. C. S. D., \& Marques, I. L. (2013). Feeding children in the immediate perioperative period after palatoplasty: A comparison between techniques using a cup and a spoon. Revista da Escola de Enfermagem da USP, 47(6), 1298-1304. doi:10.1590/ S0080-623420130000600007

Trettene, A. S., Razera, A. P. R., Maximiano, T. O., Luiz, A. G., Dalben, G. S., \& Gomide, M. R. (2014). Doubts of caregivers of children with cleft lip and palate on postoperative care after cheiloplasty and palatoplasty. Revista da Escola de Enfermagem da USP, 48(6), 993998. doi:10.1590/S0080-623420140000700005

Valer, D. B., Aires, M., Fengler, F. L., \& Paskulin, L. M. G. (2015). Adaptation and validation of the caregiver burden inventory for use with caregivers of elderly individuals. Revista Latino-Americana de Enfermagem, 23(1), 130138. doi:10.1590/0104-1169.3357.2534

Zarit, S. H., Reever, K. E., \& Bach-Peterson, J. (1980). Relatives of the impaired elderly: Correlates of feelings of burden. The Gerontologist, 20(6), 649-655. doi:10.1093/ geront/20.6.649
Ana Paula Ribeiro Razera holds a PhD in Rehabilitation Sciences from the University of São Paulo.

Armando dos Santos Trettene holds a PhD in Rehabilitation Sciences from the University of São Paulo.

Ana Vera Niquerito holds a Master in Rehabilitation Sciences from the University of São Paulo.

Maria de Lourdes Merighi Tabaquim is Professor of the University of São Paulo.

Received: Nov. 05, 2015

1st Revision: Mar. 11, 2016

Approved: Jul. 25, 2016

How to cite this article:

Razera, A. P. R., Trettene, A. S., Niquerito, A. V., \& Tabaquim, M. L. M(2017). Study the overload on children's caregivers with cleft lip and palate. Paidéia (Ribeirão Preto), 27(68), 247-254. doi: 10.1590/1982-43272768201701 